\section{ARZU ATÍK*}

\title{
Bir Hulasa Denemesi: Cevrî ve Selîmnâme'si"
}

\author{
An Attempt of Abridgement: Cevri's Selimname
}

\section{Ö Z E T}

Ceorî İbrahim Çelebi 17. yüzyılda yaşamış önemli şahsiyetlerden biridir. Gençliğinde iyi bir tahsil gören Cevrînnin günümüze ulaşan yazılarından usta bir talik kırması hattatı olduğu anlaşılmaktadır. Bir süre divan kâtipliği yaptıktan sonra geçimini kitap istinsah ederek sağlamıştır. Cevrînin Selimname'si, divanı, Hakanînin Hilye'sinin etkisiyle yazılmış Hilye-i çehar-yar-ı güzin'i, Hall-i tahkikat'l, Aynu'l-füyuz'u, Nazm-ı niyaz'ı, Yazıcı Salih'in Şemsiyye'sinin yeniden kaleme alınmasindan meydana gelmiş Melhame'si vardır. Eserleri arasında en dikkat çekici olanlardan birisi Şükrînin Selimname'sini aynı adla yeniden ele aldiğı eseridir. Şükrî, Selimname'sini ilk önce Şehsüvaroğlu Ali Bey'in anlattıkları ve kendi gözlemleriyle kaleme almış; ama Şehsüvaroğlu'nun katledilmesinden sonra yerine getirilen Koçi bin Halil'in hizmetinde çalışmaya başlayan Şükrî, Selimname'yi Koçi Bey'e okumuş, eser yanlışliklarla dolu olduğu gerekçesiyle beğenilmeyince şair, Koçi Bey'in anlattıklarına göre eserini 930/1523-1524 yilında yeniden tertip etmiştir. Bu makalede öncelikle bir tür olarak "Selimname"den, Şükrî ve eserinin yazım sürecinden kısaca bahsedilecektir. Ardından Cevrî ve eserleri hakkında bilgi verilerek Cevrînin Selimname'nin ihyası/tashihi için yazdığı mukaddimede eserin yeniden yazım sürecini nasıl anlattı̆̆ incelenip kullandı̆̆ ibarelerin/terminolojinin altı çizilecektir. Makalede bir sonuca varmaktan ziyade bu mukaddime üzerinden bazı kavramların tartışmaya açılması amaçlanmaktadır. Eserin Cevrî tarafindan tekrar ele alınmasıyla Selimname'de nasıl bir değişikliğin meydana geldiği ve bu tür eserlerin adlandirilma, simflandirlma problemi üzerinde durulmaya çalışılacaktır.

A N A H T A R K E L İ M E L E R

Cevrî, Selimname, Şükrî, ihya/yeniden yazım.

\section{A B S T R A C T}

Cevrî İbrahim Çelebi is a famous poet of the 17th century. Cevrî was well educated person and he was also a important "talik" calligrapher. He earned his living by calligraphy. He also had important works. His works are Selimname, Divan, Hilye-i çehar yar-l güzin that is written by influence of Hakanîs Hilye, Hall-i tahkikat, Aynu'l-füyuz'u, Nazm-ı niyaz, Melhame that is written by rewriting or recreating of Yazlcı Salih's Melhame. Selimname is one of his well-known works, coming out with the same title based on Şükrîs Selimname. Şükrî wrote his work twice. First, he wrote his work by the words of Şehsüvaroğlu Ali Bey and his own observation. Second, after the death of Ali Bey, Koçi Bey asked Şükrî to rewrite content of this work. This paper will focus firstly on selimname as a literary genre in Turkish tradition, touching upon Şükrî's Selimname as well. Then it will examine Cevrî's work, especially his introduction where he talks about his intention to recreate (ihya) Şükrî's Selimname with a special focus on phrases and terminology Cevrî used. My main intention is to put certain concepts into discussion and to examine possible changes that may appear as a result of Cevrîs intention of recreating Şükrî́s Selimname.

K E Y W O R D S

Cevrî, Selimname, Şükrî, recreate/rewrite.

* Okutman Dr., Boğaziçi Üniversitesi Fen-Edebiyat Fakültesi Türk Dili ve Edebiyatı Bölümü, İstanbul (atikarzu@boun.edu.tr).

** Bu makale, 11-13 Kasım 2011'de düzenlenen "Türk Dilinin ve Edebiyatının Bugünkü Sorunları ve Çözümleri Uluslar Arası Sempozyumu"nda sunulmuş bildirinin genişletilmiş hâlidir. 


\section{Giriş}

Osmanlı tarihinde saltanat dönemlerinin anlatıldığ 1 eserlerin, padişahın adıyla anılması ilk olarak Yavuz Sultan Selim döneminde görülmeye başlamış ve onun ismiyle anılan tarihler "Selimname" diye adlandırılmıştır. Bu gelenek II. Selim'den sonra birkaç istisna dışında bir süreklilik göstermemiştir. Yavuz Sultan Selim dönemini anlatan eserlerin büyük bir kısmı Kanunî döneminde kaleme alınmıştır. Bu tip eserlere ilk örnek Yavuz Sultan Selim'in emriyle İdris-i Bitlisî tarafından Farsça kaleme alınan Selimşahname'dir. Eser, sultanın doğumundan 1518 yılına kadar gelir; ama tamamlanmaz, sonradan Kanunî́nin emriyle müellifin oğlu Ebülfazl Mehmed Efendi tarafından 974/1567'de tamamlanmıştır (Uğur 2009: 440). Bizim inceleme konumuz olan Selimname ise Şükrî'nin 930/1523-24 yılında kaleme aldığı eseridir. Şükrî hakkındaki bilgilerimizin büyük kısmını Selimname'de kendisinin anlattıkları oluşturur. Şuara tezkireleri Şükrî'nin ümeradan veya Bitlis'in mahallî beylerinden biri olduğunu belirtmekle yetinmektedirler. Şükrî, Selimname'sinde birçok marifetleri olduğunu, altı dilde gazel söylediğini, Nevayî dilini bildiğini ve onun gibi Çağatay Türkçesiyle şiirler yazdığını anlatmaktadır (Argunşah 2009: 35). 15. yüzyılın ikinci yarısında Bitlis'te doğan ve ilk eğitimini Gilan ve Herat'ta aldığı bilinen Şükrî-i Bitlisî, bir süre Bitlis'te emirlik yaptıktan sonra Yavuz'un tahta çıkmasıyla birlikte İstanbul'a gelmiş, padişaha sunduğu kaside dolayısıyla hem caize hem de Diyarbakır yöresinde zeamet almış, bir süre Dulkadiroğlu beyi Şehsüvaroğlu Ali Bey ve onun halefi Koçi Bey'in maiyetinde bulunmuştur (Özcan 2010: 254). Şükrî́nin, kaynak metin olarak ele alacağımız 5829 beyitlik manzum bir tarih olan Selimname'sinde Yavuz Sultan Selim'in şehzadeliğinden başlayarak ölümüne kadar olan seferleri anlatılır. Şükrî, bu eseri Dulkadir Beyliği'ne tayin edilen Şehsüvaroğlu Ali Bey'in anlattıkları ve kendi gözlemleriyle kaleme almıştır. Şehsüvaroğlu'nun katledilmesinden sonra yerine getirilen Koçi b. Halil'in hizmetinde çalışmaya başlayan Şükrî, Selimname veya Selimîname'yi Koçi Bey'e okumuş, eser yanlışlıklarla dolu olduğu gerekçesiyle beğenilmeyince şair, Koçi Bey'in anlattıklarına göre eserini 930/1523-1524 yılında yeniden tertip edip 936/1530 yılında Veziriazam İbrahim Paşa vasitasıyla Kanunî Sultan Süleyman'a takdim etmiştir (Argunşah 2009: 36; Babinger 1982: 58-59). Görüldüğü gibi kaynak 
metin de bir yeniden yazım sürecinden geçmiştir ve her yeniden yazım sürecinde olduğu gibi bunun da bir amacı vardır. Görünürdeki amaç, eserdeki bilgi yanlışlıklarının düzeltilmesidir denilebilir; ama bu, olayın sadece okura söylenen kısmıdır. Yeniden yazımın gerçek amacının ne olduğu hakkında bir yargıya varmak için Şükrî’nin yazdığı ilk versiyonla Koçi Bey'in isteği doğrultusunda yazdığı son hâli karşılaştırılmalıdır; ama bir tahmin yürütülecek olursa asıl amacın Şehsuvaroğlu ve Şükrî́nin bakış açısı yerine Koçi b. Halil'in/yeni yönetimin bakış açısıyla olayların aktarılması olduğu söylenebilir. Bu yeniden yazımın imparatorluktaki politika değişiminin bir sonucu yapılmış olabileceği ihtimali düşünülse de bu, başka bir araştırmanın konusu olduğu için burada incelenmeyecektir.

Şükrî́nin Selimname'si şehzade Selim'in Trabzon valisiyken çıktığı Gürcistan seferiyle başlar, ölümü ve oğlu Süleyman'ın tahta geçmesiyle son bulur. Eser, kaynak olarak Osmanlı tarihçileri tarafindan kullanılmıştır. Özellikle Mısır seferiyle ilgili verdiği ayrıntılı bilgiler daha sonra Hoca Sadeddin ve Gelibolulu Âlî gibi birçok tarih yazarı tarafından alıntılanmıştır. Şükrî́nin Doğu Anadolulu olması sebebiyle Yavuz Sultan Selim'in İran seferinde ordunun konakladığı ve geçtiği yerlerin adlarını ayrıntılı olarak vermesi de takdir edilmiştir (Argunşah 2009: 36).

Şükrî́nin Selimname'si 17. yüzyılda Çerkesler kâtibi Yusuf tarafından bazı yerlerde eklemeler yapılarak -özellikle Mısır'la ilgili bölümlerdenesre aktarılmış (Babinger 1982: 198) ve Cevrî tarafından da manzum olarak tekrar ele alınmıştır (Argunşah 2009: 36-37; Özcan 2010: 255). Aşağıda Cevrî ve eserlerinden kısaca bahsedilecektir.

\section{Cevrî ve Eserleri}

Cevrî İbrahim Çelebi 1003/1595-1008/1600 yılları arasında doğduğu tahmin edilen, 17. yüzyılın ilginç şahsiyetlerinden biridir. Gençliğinde iyi bir tahsil gören Cevrî́nin günümüze ulaşan yazılarından usta bir talik kırması hattatı olduğu anlaşılmaktadır. Bir süre divan kâtipliği yaptıktan sonra geçimini kitap istinsah ederek sağlamıştır (Ayan 1993: 460). Müstakimzade, Cevrî̀nin hattı, Mevlevi dervişi hattat Abdî Efendi'den öğrendiğini bildirir; Naima ve Esrar Dede eserlerinde Cevrî́nin hattıyla yazıl- 
miş eserlerden övgüyle bahsederler Ergun 1936/III: 1052). Cevrî’nin Selimname dişında divanı, Hakanî'nin Hilye'sinin etkisiyle yazılmış Hilye-i çehar-yar-ı güzin'i, Hall-i tahkikat'ı, Aynu'l-füyuz'u, Nazm-ı niyaz'ı, Yazıc1 Salih'in Şemsiyye'sinin yeniden kaleme alınmasından meydana gelmiş Melhame'si vardır (Ayan 1993: 460).

\section{Selimname}

Eserin bilinen tek nüshası Millet Kütüphanesi Ali Emiri Manzum 1310 'da kayıtlıdır. Mukaddime 1b-2b arasında tevhit ve na't bölümleri ile başlar, ardından $2 b-5 a$ 'da eserin niçin yeniden yazıldığının anlatıldığı kısım bulunmaktadır. Bu bölümü ayrıntılı olarak incelemeden önce ilk olarak metnin yeniden yazımını kimin istediğini belirtmek önemlidir. Bu isteğin sahibi Ruznameci İbrahim Efendi'nin kethüdası Ali Bey'dir. Selimname hakkında bilgi veren çalışmaları incelediğimizde Cevrî́nin bu eseri kaleme almasının sebebi, Şükrî'nin arkaik bir dil kullanmasını eleştirip eseri devrin diline göre yeniden yazmak istemesi; hatalı bulduğu bu çalışmayı yaptığı düzeltmelerle tekrar nazma çevirmesi gibi çok kısa cümlelerle özetlenmiş ve bunun ona Ali Bey tarafından tevdi edildiğinden bahsedilmemiştir. Yukarıda da belirtildiği gibi bu makalede Cevrî́nin kaynak metni nasıl aktardığı ve yenilediği üzerinde durulacaktır. Bu amaçla öncellikle ve özellikle mukaddimede eserin niçin yeniden yazıldığını açılarken hem Ali Bey'in hem de Cevrî́nin kullandığı kelimeler/söylemler incelenecektir. Ayrıca başlıkta eserin bir hülasa/özetleme denemesi olduğuna dikkat çekilmesinin nedeni, Selimname'de Cevrî́nin bizzat özetleme yaptığını söylememesine rağmen Osmanlı Müellifleri'nde Selimname için "zamāne uslūb-1 şi'rine tevfīḳan tenḳị edilerek naẓmedilmiştir." (Bursalı Mehmed Tâhir 2000/III: 72)1 denilmesidir. Eseri tanımlamak için bir şeyin fazla ve lüzumsuz kısımlarını çıkartıp düzeltme, ayıklama, arıtma anlamında "tenkih" kelimesi kullanılmıştır. Eser incelendiğinde bu özetlemenin mahiyeti ortaya çıkar. Cevrî́nin Selimname'si kaynak metinden yaklaşık 1500 beyit eksiktir. Bu

${ }^{1}$ Cevrî́nin Selimname adlı eseri olduğu bibliyografik kaynaklar arasında sadece Osmanl Müellifleri'nde geçer. Diğer kaynaklarda bu eserin Cevrî̀nin eserleri arasında sayılmaması dikkat çekicidir. Bkz. Ergun 1936/III: 1062. 
tür yeniden yazım süreçlerinde özetlemenin ister açıkça belirtilsin ister belirtilmesin önemli bir unsur olduğu söylenebilir. Özetlemeyi açıç̧a söylemeyen eserlere gelenekte rastlanırken -bazı mesneviler örneğinde olduğu gibi- özetlemenin açıkça belirtildiği örnekler de mevcuttur; Ahmet Mithat Efendi'nin Hulasa-i Hümayunname'si gibi. Elimizdeki mukaddime dikkatli bir şekilde incelediğinde Zehra Toska'nın "Ahmet Mithat Efendi'nin Bir Diğer Eseri: Hulâsa-i Hümâyunnâme" adlı makalesinde ortaya çıkan "bu tarz eserlerin incelenmesinde bir ortak yapının" (Toska 2007: 318) olabileceği fikrinin sağlamlaşmasında önemli bir örnek olabileceği düşüncesi uyanır. Hulasa ve Selimname'deki yeniden yazım sürecinin paralelliği dikkat çekicidir. Bu paralelliğe makalenin ilerleyen bölümlerinde yeri geldikçe değinilecektir.

$2 b-5 a$ 'da eserin yeniden yazım nedenlerini ve eserin yazımında hangi yönleriyle kaynak metinden ayrıldığı üzerinde durulduğu "der bisāṭ-1 muḳaddime-i sebeb-i taṣhīḥ-i Selīmī-nāme” bölümünü ayrıntılı olarak incelenmeye geçmeden dikkatimizi çeken, başlıktaki "tashih" kelimesidir. Böylece eserle ilgili ilk terimimiz "tashih" olarak ortaya çıkar, diyebiliriz. "Bir kimsenin sağlı̆̆ını iâde etme, iyileştirme; daha iyi ve daha doğru hale getirmek, düzeltmek" gibi anlamları içeren tashih kelimesiyle Şükrî́nin hasta/bozuk olan eserinin Cevrî tarafından nasıl düzeltileceği ve iyileştireceğinin anlatılacağı daha başlıktan verilen bir mesaj olarak algilanabilir.

Mukaddimenin başında Cevrî, sebepsiz yere Ali Bey'in yanına gittiğini bildirir ve bize Ali Bey'in ahlâkının güzelliğinden, ilme ve özellikle tarihe olan merakından, tarih ilminin faziletlerinden bahseder ve ardından Ali Bey'in kendisine izzet ü ikramda bulunup eline bir kitap verdiğini şu beyitlerle anlatır:

68 Dil-nüvāzāne idüp bezl-i kerem

Ḳıldı bezminde fakīri muḥterem

69 Eyleyüp şāyeste-i 'izz-i hitạāb

Destüme șundı müdevven bir kitāb (3b) 
Ali Bey elindeki kitabı mevzun ve Rumî elbise giymiş bir güzele benzetir, kitabın müellifini söyler.

70 Didi bu nüsha Selīmī ḩāmedür ${ }^{2}$

Dilber-i mevzūn u Rūmī cāmedür

71 Eylemiş Şükrī tahallüṣ nāẓımı

Ṭab'ınuñ bu hidmet olmış lāzımı (3b)

Bundan önceki beyitlerde Ali Bey'in her ilimden özellikle tarihten anladığını bildiren Cevrî, okuyucuda onun bir tarih kitabı ile ilgili vereceğe hükme güvenebileceği algısını oluşturur. Döneminin bilinçli bir tarih okuru/bir entelektüeli olarak Ali Bey, elindeki yaklaşık yüz yıl önce yazılmış bir tarih kitabı hakkında eleştirilerini sıralar, bu eleştiriler aynı zamanda dönemin okur algısını/zevkini de yansıtır. Ali Bey'in eserle ilgili eleştirileri şöyledir:

72 Gerçi vardur sözlerinüñ șı̣hhati Hāṭ̂rum gösterdi aña rag̉beti

73 Līk yoḳdur ḳālıb-ı nazmında rūḥ Zevḳ virmez ādeme feyż-i fütūh

$74 \quad$ Her ne deñlü olsa ma'nāsı dürüst Dil-küşā olmaz yine elfāzı süst (3b-4a)

Yani bir eserin içeriği, konuyu anlatış şekli doğru olabilir; ama nazminda bir ruh yoksa ve anlatılan konular insana zevk vermiyorsa; anlattıkları ne kadar doğru olursa olsun, eser iç açıcı olmaz, rahat okunmaz. Ali Bey, durum tespiti yaptıktan sonra bu cevherin gerçek değerini Cevrî gibi bu ilmin üstadı olan birisinin vereceğini belirtir ve bu işi nasıl yapacağını da Cevrî́ye söyler.

79 Ṭarh idüp ebyāt-1 nā-mevzūnını

Rūşen eyle hāme-i mażmūnını

\footnotetext{
${ }^{2}$ Nüshada çok açık şekilde "ḩāme" olarak yazılmış olan bu kelime aynı zamanda "nāme" olarak da okunabilir.
} 
80 Dest urup kilk-i beyān u hiikmete

Ko bu naẓmı siḥ̣ ile bir șūrete

81 Rūḥ vir lafẓ-1 lațīfüñle aña

Tā ki virsün sözleri rūḥa șafā

82 Nāmimuzla olsun iḥyā bu eserer

Bu eșerdür hāậllı nev'-i beşer (4a)

Kısaca; eserden vezinsiz beyitleri atmalı, mazmunu aşikâr etmeli; beyan ve hikmet kalemiyle bu nazmı başka bir surete sokmalı; anlamı daha ince bir lafızla, sözle ifade etmeli ve bu sözler okuyanın ruhuna safa vermeli; yani eseri ihya etmelidir.

Ali Bey'in yeniden yazımın nasıl yapılacağını bildirdiği bu beyitlerde kullanılan "tarh etmek" yani atmak, çıkarmak, "ruşen eylemek" aşikâr kılmak, "kilk-i beyan u hikmet" beyan ve hikmet kalemi, "ruh vermek", "ihya" yani yeniden can vermek gibi kelimeler bu eserin yazım süreci için anahtar kelimelerdir denilebilir. Bir cesetten/ruhu olmayan bir bedenden farksız olan Şükrî́nin eserine ruh üflenecek ve ihya edilecek/yeniden hayata döndürülecektir. Burada Ahmet Mithat'ın Hulasa's1 ile Selimnaménin yeniden yazım süreçlerini karşılaştırdığımızda her ikisinde de sürecin bir otorite tarafından ve onun seçtiği nüsha üzerinden belirlendiği dikkat çekici bir ortaklık olarak görülebilir.

Ali Bey'in isteklerinin ardından Cevrî̀nin esere nasıl yaklaştığına bakılacak olursa onun bu yazım eyleminin, içinde bulunduğu geleneğin mutat olarak yaptığı bir edebî yenilenme ve üretme sürecinin bir parçası olup olmadığ irdelenmelidir. 19. yüzyılda bile devam edegelen bu geleneği Ahmet Mithat Efendi Hulasa'sında “tecdid etme" (Toska 2007: 29697) kavramıla karşılarken Cevrî̀nin başlıkta "tashih" sonrasında ise "ihya" kelimesiyle karşıladığı görülür. Kelimeler farklı olsa da ikisinin de yapmak istediği şey aynıdır: Daha önce yazılmış önemli eserleri, o dönemin okurunun zevkine ve kelime dağarcı̆̆ına uygun olarak yenilemek.

\footnotetext{
${ }^{3}$ Bu ifadeyle "Muhakkak şiirde hikmet ve beyanda sihir vardır." hadisine de telmih olduğu söylenebilir.
} 
Hatta Ahmet Mithat bunu bir adım ileriye götürerek eserin sonsuza kadar yaşaması için zamanı geldikçe bu yenilenmenin gerekli olduğunu vurgular (Toska 2007: 297).

Cevrî́ye göre manzum bir eser olan Selimname'de ilk yapılması gereken şeylerden biri vezninin düzeltilmesi; ardından da eskiyen kelimelerin ve ibarelerin değiştirilmesi; noksan ve hatalı beyitlerin düzeltilmesidir. Cevrî bunu şu beyitlerle açıklar:

86 Ol Selīmī-nāmeye itdüm naẓar Naẓmını mi'yāra çekdüm ser-be-ser

87 Gördüm el-ḥaḳ vezninüñ noḳṣānı var Ya'nī ol cevher degül kāmil 'ayār

88 Ekṣer-i elfāẓı Türkīi ḳadīm

Ekșer-i ebyātı ma' yūb u saḳīm (4a-4b)

$\mathrm{Bu}$ düzeltme işleminde en çok dikkati çeken ibare "Türkî-i kadim"dir. 17. yüzyılda konuşulan Türkçe, Şükrî́nin eserinde kullandığı yer yer Çağatay ve Azeri Türkçesi özellikleri içeren Türkçeden çok farklıdır. Cevrî, bu eski Türkçe kelimelerin yerine çoğu zaman kendi döneminde kullanılan karşılıklarını yerleştirir. Böylece eserin eskimiş/ölmüş olan dilini de ihya etmiş, ona yeniden hayat vermiş olur.

Cevrî ihyayı nasıl yaptığını anlattıktan sonra eksik yönlerine de değinir. Şair, nazmı ne kadar düzeltmeye çalışsa da kaynak metindeki hataların, kafiyedeki aksaklıkların tamamen ortadan kaldırılamadığını, nüshanın tamamen lağvedilemediğini, bu ayarı bozuk nazmın ancak sihirle başka bir hâle dönüşeceğini şu beyitlerle açıkça bildirir:

94 Çünki aldum 'ahdüme bu hidmeti

Naẓmina virdüm kemāl-i ș̣ḥhati

95 Nüsḩa bi'l-külliyye mensūḩ olmadı

Ṣūret-i terkībi memsūh eyledi

96 Ol ḳadar var kim bu naẓm-1 nāsere

Siḥr ile girdi libās-1 āhhere 
97 Ger ḳavāfīsinde anuñ cā-be-cā

Var ise bir niçe müsta' mel edā (4b)

Aşağıdaki beyitte görüleceği üzre Cevrî, bunların sorumlusu olarak "sâhib-i telif" Şükrî́yi gösterir ve kendini "sâhib-i tertîb" olarak adland1rarak sorumluluğu üzerinden atar:

98 Șāhib-i te'līfedür andan su'āl

Șāhịb-i tertībe yoḳdur ḳil u ḳāl (4b)

Bu noktada dikkat çekici terimlerden biri "sâhib-i tertîb"dir. Cevrî kendini bu eserin sahib-i telifi değil sahib-i tertibi olarak verir; kendini eseri düzene koyan kişi olarak konumlar. Ama burada nazmın kelime anlamına baktığımız zaman Cevrî̀nin sâhib-i tertîple kastettiği anlam daha açık bir şekilde ortaya çıar. Nazm kelimesi "dizme, tertip etme, sıraya koyma" anlamlarıyla karşılanmaktadır. Cevrî, sahib-i telif olmadığını özellikle vurgular ve böylelikle onun sâhib-i telifi nasıl tanımladığı da gözler önüne serilmiş olur. Ona göre sâhib-i telif, konuyu ilk kez işleyen kişidir; fakat $\mathrm{o}$, konunun içeriğine, çatısına çok fazla müdahale etmeden metne şekil veren, metni düzene koyan kişi; yani "sâhib-i tertîb"dir.

Cevrî, bütün bunlara rağmen eseri ihya ederken kaynak metnin müellifinin de hakkını teslim eder. Hikâyenin içerik olarak kendi dönemi ve bu anlayışa sahip geleneğin kriterleri için iyi bir eser olduğunu vurgular. Cevrî, Firdevsî Şehname'yi yazarken Selimname'yi görseydi Rüstem'in hikâyesi yerine bu hikâyeyi yazarak âlemce tanınırdı deyip Şükrî̀ye ve eserine verdiği değeri de mübalağalı bir şekilde belirtir.

89 Lìk ammā mevżi 'i gāàyet bülend

Gevher-i mażmūnı Firdevsī pesend

90 Naẓm-1 Şehnāme iderken ol eger

Gūşına irseydi bu rengīn ḩaber

91 Terk iderdi dāstān-1 Rüstemi

Bu hịikāyetle țutardı 'ālemi 
92 Līk inșāf olsa Şükrī ol zamān

Kāadir olduḳça anı ḳılmış beyān

93 Kendü maḳdūrınca itmiş bir eserer

Eylemiş bu mülk-i fānīden güzer (4b)

Cevrî, mukaddimenin sonlarında ise her ne kadar tarih eserleri çoğunlukla mensur olarak yazılsa da manzum tarihlerin de herkes tarafından sevilen, rağbet edilen eserler olduğunu belirtir ve böylece dönemin tarih algısını verir. Son olarak bu eserin ihya edilmesine sebep olan Ali Bey'in adının sonsuza kadar hayır ile yad edilmesiyle Selimname'nin ihya tarihi verilir. Tarih beyti hesaplandığında ihyanın 1037/1627-28'de yapıldı̆̆ı görülür.

112 Oldı bu ị̣yāya tārīhn-i celī Hayr ile cāvīd ola nām-1 'Alī (5a)

\section{İçerik, dil ve anlatım özellikleri bakımından iki Selimname'nin karşılaştırılması:}

Mukaddimeden sonra Cevrî asıl konunun anlatıldı̆̆ı bölüme "Selīmīnāme-i Şükrī be-taḳrīr-i Ḳoçī Bey ser-bevvābān-1 dergāh-1 'ālī der evā'il-i salțanat-i Sulțān Selīm b. Bāyezīd Hāan 'aleyhi raḥmetü'r-raḥmān" başlığı ile 5b'de geçer. Asıl konunun anlatıldığı bölümlerde, Cevrî́nin mukaddimede söylediklerini nasıl uyguladığına bakacak olursak ilk karşımıza çıkan şey, yukarıda da belirttiğimiz gibi, $5829^{4}$ beyit olan kaynak metnin Cevrî tarafından 4264 beyte indirildiği; yani 1565 beytin atıldığı görülür. Bu kısaltmanın nerelerde yapıldığı önemlidir. Cevrî, bu kısaltmaları daha çok tasvirlerde, Şükrî tarafından iki beyitte anlatılan meseleleri tek beyitte anlatarak ve özellikle bölüm girişlerinde, savaş sahnelerini anlattığı bölümlerde yapar ve aynı zamanda bu tasvirlerde değişikliklerin fazlalılığı göze çarpar. Ayrıca eserin son kısımlarında Cevrî önemli bir kısaltmaya gider. Cevrî, eseri Yavuz Sultan Selim'in ölümü;

${ }^{4}$ Toplam beyit sayısı Argunşah'ın neşrettiği metne göre verilmiştir. Bundan sonraki beyit numaraları da aynı yayından verilecektir: Şükrî-i Bitlisî, Selîm-nâme, Haz. Mustafa Argunşah, Kayseri: Erciyes Üniversitesi, 1997. 
dua bölümü ve 4264. beyitte telif tarihi 930/1523-24'ü vererek bitirir. Şükrî́nin Selimname'sinde bundan sonra bulunan Yavuz Sultan Selim için mersiye, Sultan Süleyman'ın tahta geçişi, Şükrî́nin kitabın ve kendi macerasını anlattığı hâtime bölümlerini içeren 178 beyti tamamen atar. Atlamaların yanı sıra Cevrî bazı bölümlerde kaynak metinden tamamen ayrılır, birçok beyti kendi üslubuna göre söyler veya Şükrî́nin ilk mısraını alsa da ikinci mısraı genellikle farklıdır ya da en azından arka arkaya benzer kafiyeler kullanılmış beyitleri kafiye kelimesini değiştirerek kullanır. Özellikle Yavuz Sultan Selim'in ölümünün anlatıldığı 64 beyitlik bölümde Şükrî́den çok az yararlanır. Bu bölümde sadece 4 beytin bir mısraı ve 6 beyit ortaktır. İki eserin bölüm başlıkları karşılaştırıldığında Cevrî́nin neredeyse bütün bölüm başlıklarını değiştirdiği, bazı yerlerde iki bölümü birleştirdiği ve nadir de olsa Şükrî́nin bölüm başlığı koymadığı yerlerde başlık kullandığı görülür. Ayrıca hikâye anlatma açısından da iki eser karşılaştırılırsa Cevrî̀nin bir konudan diğerine geçerken aradaki bağlantıyı geçiş beyitleri ile sağladığı görülür; ama Şükrî Selimname'sinde konular arasında geçiş beyitleri kullanmaz.

Cevrî́nin Selimname'sinin kaynak metinden ayrıldığı bu noktalar d1şında Cevrî́nin özellikle dil ve üslûp açısında kaynak metinden farkl1laştığ1 görülür. Bu farklılıkların esere yansıması dört alt başlıkta toplanabilir: eskiyen kelimelere yeni karşılıklar bulma, yardımcı fiilleri ve ekleri değiştirme, kelimeleri özellikle tamlamalı kullanma ve yer adlarını değiştirme.

Eskiyen kelimelere yeni karşılıklar bulma: Mukaddimede eserin ihya edilmesinin en önemli sebebi olarak gösterilen eski kelimeleri Cevrî̀nin hangi kelimelerle karşıladığına aşağıda bazı örnekler verilmiştir: ${ }^{5}$

dapar (Ş1): bulur (C1); benden de ger dinler olsang ḳıșșayı (Ş245): ḳıșșayı benden iderseñ istimā' (C155); dapdı (Ş377): oldı (C263); müjde birle (Ş504): beşāretle (C385); uş (Ş 258, 761, 3533): pes (C159, 596, 2799), uş (Ş385, 3328, 3359; 3462) hem (C270, 2632, 2656; 2746), uş (Ş505) çün

${ }^{5}$ Ş kısaltmasıyla verilen beyit numaraları Argunşah'ın yayınından; C kısaltmasıyla verilen beyit numaraları ise Ali Emiri Manzum 1310'da konunun anlatıldığ 5 b'den itibaren Selimname'ye tarafımızdan verilen beyit numaralarıdır. 
(C386), uş (Ş 808): kim (630); barça (Ş542): cümle (C418); ḳamu (Ş3430): cümle (C2718); dil (Ş71, 73): zebān (C40), nuṭ̂ (C43); dartıla (Ş80): veznile (C47); düzgil (Ş220): naẓm it (C136); söz (Ş425): peyām(C311); gönderdi (Ş426): hāàżır itdi (C312); ata çıdı (Ş431): hāàżır oldı (C315); leşker (Ş367): 'asker (C252) ${ }^{6}$ toz (Ş455): gerd (C336); yayan (Ş473): piyāde (C352); diñleñ (Ş716): gūş eyleñ (C551); ārzū (Ş771): hāhiş (C606); dirildi (Ş432): cem oldı (C316); dirdi (Ş5496): cem’ itdi (C4136); ılgadı (Ş5566): yürüdi (C4194) ${ }^{7}$ özge (Ş4205): gayrı (C3233); eytdiler (Ş4196): didiler (C3226); ḳarañu gice (Ş4982): şeb-i tārīk (C3772) evvel (Ş3642, 3816): aḳdem (C2868, 2954); öñdin (Ş3431): aḳdem (C2719); söyledi (Ş3526): didi (C2795); at u er (Ş3480): esb ü merd (C2758); öpdi el (Ş3225): dest-būs idüp (C2565); Çalab (Ş2520): Hudā (C2015); ḳancaru (Ş2079): ḳanda (C1646); og̉lı (Ş2113; 2725; 2667): zāde (C1687; 2162; 2113); og̉lı (Ş2195): ibn (C1766). ${ }^{8}$

Yukarıdaki örneklerde görüldüğü üzre 17. yüzyılda bazı Türkçe kelimelerin kullanımdan kalktıkları veya kullanımın azaldığı, onların yerine Arapça ve Farsça karşılıklarının yerleştiği görülür.

\section{Kelimelere gelen yardımcı fiilleri ve eklerin değiştirilmesi:}

ġazā aldı (Ş324): ġazā etti (C209); te'emmül it (Ş350): te'emül ḳıl (C236); 'işret itti (Ş483): 'işret ḳıldı (C362); zebūn itgeç (Ş540): zebūn eyler (C416); göklere aġdı (Ş891): göklere çıḳdı (C702); diñlegeç (Ş327, 887): diñledi (C215, 687); itmen (Ş338): itmem (C226); Tañrıya itti tevekkül (Ş2370): eyleyüp Haḳka tevekkül (C1913); gaziler (Ş369; 3434, 3745): gaziyān (C253, 2722, 2912); olça (Ş347): ol ki (C209); olısar (Ş128): ol1caḳdır (C95); ögrendi gazāyı (Ş332): aldı resm-i cengi (C220); dirsiz (Ş328): dirsin (C216); dog̉geç (Ş435): țog̉dukç̧a (C319) ; țuttı nizāam

\footnotetext{
${ }^{6}$ İki şair, bu iki kelimeyi birbirinin yerine kullanır; ama Cevrî çoğunlukla "asker" kelimesini, Şükrî ise "leşker"i tercih eder.

${ }^{7}$ Cevrî çok nadir olarak "1lġadı" kelimesini kullanır; ama çoğunlukla burada olduğu gibi farklı kelimelerle de karşılar.

${ }^{8}$ Cevrî zaman zaman "oğlı" kelimesini de kullanır.
} 
(Ş5071): buldı niẓām (C3839); irsāl itdi (Ş3423): irsāl eyledi (C2711); it hücūm (Ş3447): ḳıl hücūm (2732); ḥazer it (3363): ḥazer ḳ1l (26609)

Yukarıdaki örneklerin bir kısmında görüldüğü gibi eski Anadolu Türkçesine ait eklerin terk edildiği ve özellikle çoğul ekinin çoğunlukla Farsça şeklinin kullanıldığı görülür.

\section{Kelimelerin tamlamalı kullanılması:}

țfliyet 'ahdinden (Ş280): 'ahd-i țıfliyetden (C176) Şaḥne çayın (Ş2129): çayır-1 Şaḥne (C1703); cān ḳorhusından (Ş2149): bīm-i cān (C1719); Molla Kāsım köyidür (Ş2260): kūy-1 Molla Kāsım (C1819); pādişāh emriyle (Ş2273): emr-i sulțānī ile (C1831); 'azm itti Kuıılbaşa (Ş3300): 'azm-i Kızılbaş (C2612); dīn 'adūsı (Ş562): düşmen-i dīnin (C435); gayret odı (824): nār-1 ġayret (645); ġażab deryāsı (Ş1351): deryā-yı ġażab (C1102); İskender Paşa (Ş3593): Paşa-y1 İskender (C2840) şāh dergehi (Ş3493): dergeh-i şeh (C2767) Allah emri (Ş3270): emr-i Haḳla (C2597); 'irfān menba' 1 (Ş3234): menba'-1 'irfān (C2570).

Burada da görüldüğü gibi Türkçe tamlamalar yerine kelimeler Farsça tamlamalar hâlinde kullanılmıştır.

Eskiyen kelimelere yeni karşılıklar bulma, kelimelere gelen yardımcı fiillerin ve eklerin değiştirilmesi ve kelimelerin tamlamalı kullanılması maddelerinde görülen değişiklikleri Cevrî́nin dili kullanımındaki kişisel tercihi olarak yorumlamak mümkündür. Fakat bu eser özelinde, 17. yüzyılın değişen kültür hayatının ve beğenisinin eserlerde Türkçe kelimeler ve kurallar yerine Arapça ve Farsçasını kullanma eğilimini artırdığının bir göstergesi olarak değerlendirilebilir.

\section{Yer adlarının değiştirilmesi veya hiç alınmaması:}

Cevrî eserin içeriğine dokunmadığını söyler; ama yer adları çoğunlukla farklı olarak verir. Bu da aslında eserin içeriğine bir müdahale ola-

\footnotetext{
${ }^{9}$ Ş 3366'da kelime "ḥažer ḳılsun" olarak da kullanır; Şükrî’de bu kelime iki yardımcı fiille de kullanılırken Cevrî tek yardımcı fiille karşılar. Bkz. C2662.
} 
rak alınabilir. Yer isimlerinde yapılan değişikliklerin Cevrî́nin yaşadığı dönemde o yerleşim yerlerinin adlarının değişmiş/değiştirilmiş olabileceğinden kaynaklandığı söylenebilir. Değişikliklerin yanı sıra bazı bölümlerde Şükrî'de olan yer isimleri Cevrî'de yoktur. Örneğin Ş281'de "Gürciye şehzādenüñ 'azmin didüm” misraiyla Gürcistan'a yapılan seferlere gönderme yapılır; Cevrî̀de bu beytin karşılığında C177'de "gerçi kim şehzādenüñ 'azmin didüm" şeklinde değiştirilerek Yavuz Sultan Selim'in nereye gittiği belirtilmemiştir. Değiştirilen yer isimlerinden bazıları aşağıda verilmiştir:

Ġazye (4857): Ġazze (3671) 'Allān (Ş3806): Ġıllān (C2946) Issıçermik (Ş3369): Çermik (C2665) Kara Kanḳal (Ş2258): Kara Konaḳ (C1818); Diyār1 bekr (Ş3235): mülk-i Āmed (C2571); Ġayb Işığuñ (Ş2305): Eyyūb Şeyhiñ (C1855).

\section{Vezin}

Cevrî́nin eseri yeniden ele alma sebeplerinden bir diğeri de Şükrî́nin eserinin vezin kusurlarıdır. Uygulamada çoğunlukla vezin kusurlarını düzelten Cevrî bazı beyitlerde kendisi de vezni bozan, zorlayan kelimeler kullanır. Örneğin Ş73'te ilk kelime "dilüme" ile bozulan vezin C43'te "nuțuma" diyerek düzeltilir. Ama Ş56'da düzgün olan vezin Cevrî tarafından "luṭfuñ" kelimesi yerine "raḥmetüñn" kelimesini kullanılarak bozulur (C32).

Cevrî́nin Selimname'sinin dil-üslûp özellikleri açısından kaynak metinden ayrılmasının yanı sıra anlatıya eklediği bazı öğeler açısından da kaynak metinden farklılaşır. Bu öğelere örnek olarak Mevlevi-meşrep olması dolayısıyla Cevrî́nin esere eklediği ayrıntılardan biri Selim'in sefer için yola çıktığında Konya'ya gitmesi ve orada Mevlânâ'nın türbesini ziyaret etmesi, oradaki dervişlere ikram ederek yüz bin akçe vermesi verilebilir (C1660-61). Ayrıca şahın bismillah ile ata binmesi (C1914); mektubun kırmızı mumla mühürlenerek gönderilmesi (C3969) şeklindeki kültürel öğelerdir. Eklenen bu ayrıntılar ve buna benzer diğerleri Cevrî̀nin metni sadece biçimsel açıdan yeniden yazmayı amaçlamadığı aynı zamanda Selimname'nin genel karakterini de değiştirip metnin "şehirli" bir karaktere bürünmesini istediği söylenebilir. 
Bu bağlamda Cevrî́nin Selimname'yi yeniden yazması, İstanbullu bir aydının kendi şehirli okur kitlesi -özelde Ali Bey- tarafından beğenilecek bir eser oluşturma amacıyla ilişkilendirilebilir.

Son olarak elimizdeki tek nüshanın hususiyetleri ile ilgili dikkat çekici bir özellik göze çarpmaktadır. Bu nüsha, Argunşah tarafından yayımlanan Şükrî́nin Selimname'sinde nüsha farkı olarak alınan British Museum Or. 39 numaralı (Şükrî 1997: 23) nüshayla çok büyük ortaklıklar içerir. Bu ortaklıklar ister istemez akla British Museum'daki bu nüshanın Ali Bey'in Cevrî̀ye verdiği Selimname nüshası olabilir mi sorusunu akla getirir; ama nüshaları birebir karşılaştırmadan kesin bir yargıya varılamaz.

\section{Sonuç Yerine}

Cevrî, Ali Bey'in emriyle kaleme aldığı bu manzum tarihî kaynak metne göre üçte birini atarak özetler veya daha doğru bir ifadeyle gereksiz kısımları atarak metnin özünü verir, devrinin diline ve zevkine göre yeniler ve her ne kadar içeriğine dokunmayacağını söylese de içeriğe müdahaleleri olur. Bu müdahalelerle, Cevrî esere hem kendi bakış açısı ve beğenisini hem de döneminin temayüllerini yansıtmıştır. Kaynak metnin amacı daha didaktik, yaşanılan olayları en doğru ve ayrıntılı şekilde anlatmakken Cevrî, muhtemelen döneminin siyasî temayüllerine göre bazı olayları yeniden yorumlar. Bu değişiklikler kendinin de belirttiği gibi kaynak metni tamamen ortadan kaldırmak amacıyla değil, ona başka/yeni bir elbise giydirmek için yapılan müdahalelerdir.

$\mathrm{Bu}$ eserin yazım sürecine ait terimler olduğunu düşündügüumüz tashih, tarh etmek, ruşen eylemek, kilk-i beyân u hikmet, ruh vermek, ihyâ, Türkî-i kadîm, sahib-i tertîb kelimelerinin tekrar altını çizerek Cevrî̀den bahseden Osmanlı Müellifleri hariç bibliyografik kaynaklarda Cevrî́nin eserleri arasında sayılmayan ve sadece bir nüshası olan Selimname, sadece bir diliçi çeviri olarak mi nitelenmeli yoksa Zehra Toska'nın Hulasa'da önerdiği buna benzer eserleri "tecdid etme" veya bu eser özelinde "ihya etme" kavramı açısından mı bakılmalı sorusuna cevap aranmalıdir. 


\section{Kaynakça}

Argunşah, Mustafa (2009), "Türk Edebiyatında Selimnameler", Turkish Studies International Periodical For the Languages, Literature and History of Turkish or Turkic 4/8, 31-47.

Ayan, Hüseyin (1993), "Cevrî”, TDV İslâm Ansiklopedisi, 7, 460-61.

Babinger, Franz (1982), Osmanlı Tarih Yazarları ve Eserleri, Çev. Coşkun Üçok, Ankara: Kültür ve Turizm Bakanlığı.

Bursalı Mehmed Tâhir (2000), Osmanlı Müellifleri, Ankara: Bizim Büro Basımevi.

Cevrî, Selimname, Millet Kütüphanesi, Ali Emiri Manzum 1310.

Ergun, Sadettin Nuzhet (1936), Türk Şairleri (III cilt), İstanbul.

Özcan, Abdülkadir (2010), "Şükrî-i Bitlisî", TDV İslâm Ansiklopedisi, 39, 25456.

Şükrî-i Bitlisî, Selîm-nâme, Haz. Mustafa Argunşah, Kayseri: Erciyes Üniversitesi, 1997.

Toska, Zehra (2007), "Ahmet Mithat Efendi'nin 'Bir Diğer Eseri': Hulâsa-i Hümâyunnâme", Journal of Turkish Studies-Türklük Bilgisi AraştırmalartIn Memoriam Şinasi Tekin II, XXXI/II, 291-318.

Uğur, Ahmet (2009), "Selimnâme", TDV İslâm Ansiklopedisi, 36, 440-41. 